\title{
PENDEKATAN KONSEP BIOPHILIC DESIGN DALAM PERANCANGAN TEMPAT PUBLIK
}

\author{
Josua Keneth ${ }^{1)}$, Doddy Yuono ${ }^{2)}$ \\ 1)Program Studi S1 Arsitektur, Fakultas Teknik, Universitas Tarumanagara, josuakeneth@gmail.com \\ 2) Program Studi S1 Arsitektur, Fakultas Teknik, Universitas Tarumanagara, doddyy@ft.untar.ac.id
}

Masuk: 28-07-2021, revisi: 11-08-2021, diterima untuk diterbitkan: 23-10-2021

\begin{abstract}
Abstrak
Banyak hal yang telah terjadi di dalam kehidupan sehari - hari kita sebagai seorang manusia yang memiliki kecenderungan untuk tertekan, stres dan hal ini memiliki dampak yang sangat besar kepada manusia itu sendiri terlebih di masa pandemi COVID-19. Stres tersebut terjadi akibat stresor yang ada di kehidupan kita, stresor adalah sesuatu kondisi atau situasi yang menyebabkan stres atau hal yang membuat otak kita mengluarkan hormon stres / hormon koritsol. Hormon ini sangat berpengaruh dan dapat menyebabkan perubahan secara fisiologis seperti susah tidur, pucat, dan kelelahan, lalu perubahan suasana hati, karakter, perilaku dna juga emosi. Untuk menghadapi permasalahan ini, arsitektur dapat menjawab dengan biofilik arsitektur, dengan metode layering dan city grid, kita dapat menentukan kebutuhan ruang untuk bersosialisasi, rotasi dan sirkulasi pengguna bangunan, akses, rotasi, pelapisan, pergesaran, dan juga leveling yang memberikan ruang untuk eksplorasi dalam hal tersebut untuk menghasilkan nilai program, fungsionalitas dan estetika untuk kebutuhan penyembuhan. Hal ini akan menciptakan suatu kesinambungan antara tapak dan sekitar serta pengguna bangunan itu sendiri sehingga terjadi suatu ekosistem sehat yang berkelanjutan.
\end{abstract}

Kata kunci: stres; stresor; penyembuhan; ekosistem; biofilik; sejenak

\begin{abstract}
Many things have happened in our daily lives as humans who have a tendency to be depressed, stressed and this has a huge impact on humans themselves, especially during the COVID-19 pandemic. Stress occurs due to stressors in our lives, stressors are conditions or situations that cause stress or things that make our brains release stress hormones / cortisol hormones. This hormone is very influential and can cause physiological changes such as insomnia, paleness, and fatigue, then changes in mood, character, behavior and emotions. To deal with this problem, architecture can answer with biophilics architecture, with layering and city grid methods, we can determine space requirements for socializing, rotation and circulation of building users, access, rotation, layering, shifting, and also leveling which provides space for exploration in it is to produce programmatic value, functionality and aesthetics for healing needs. This will create a continuity between the site and its surroundings and the users of the building itself so that a healthy, sustainable ecosystem occurs.
\end{abstract}

Keywords : stress; stressor; healing; ecosystem; biophilic; for awhile

\section{PENDAHULUAN} Latar Belakang

Beyond ecology terpecah menjadi 2, yaitu lingkungan alam biotik dan abiotik. Alam biotik, ketika adanya percepatan maka terbentukah virus, evolusi biologi, dsb. Dari lingkungan abiotik yang mengalami percepatan, maka muncul, ekonomi, politik, sosial budaya, dsb. Hal ini menyebabkan manusia mempunyai rutinitas dan kejenuhan yang terus - menerus terjadi di kehidupan sosial keseharian manusia itu sendiri. Ketika hal ini terjadi maka muncul masalah seperti ketidakperdulian, individualis, kurangnya waktu untuk diri sendiri, perubahan besar 
dalam hidup, sifat individualistik dan masih banyak lagi. Hal tersebut dapat menjadi stressor bagi manusia. Alam sendiri dapat menjadi suatu solusi dengan pelarian manusia dari keterbatasannya tersebut. Manusia butuh pelarian ke alam, tetapi alam tidak butuh manusia untuk tetap hidup.

Kesinambungan ini yang harus dicari melalui bidang arsitektur yang telah berevolusi, disini, peran manusia sangat penting untuk bekerja sama dengan alam sehingga dapat berjalan berdampingan tanpa merusak satu sama lain, menurut data dari sumber Terrapin Bright Green LLC (2014) desain biophilic dapat membantu dalam meredakan stress dan memiliki tahapan tahapan tersendiri untuk menghadapi stress dan pelarian manusia itu sendiri.

Selain itu, desain biofilik sendiri dapat dikaitkan dengan beyond ecology, yang berkembang dari biophilia (afinitas bawaan kehidupan atau sistem kehidupan yang peduli akan kehdiupan lainnya) lalu berevolusi (percepatan) menjadi suatu konsep desain dalam bidang arsitektur.

\section{Rumusan Permasalahan}

Berangkat dari permasalahan stress yang terjadi pada masyarakat umum di lingkungan sekitar, menurut data riset yang dilakukan UMS, Sekitar 1,33 juta penduduk DKI Jakarta diperkirakan mengalami gangguan kesehatan mental atau stres. Angka tersebut mencapai $14 \%$ dari total penduduk dengan tingkat stres akut (stres berat) mencapai 1-3\%.

- Bagaimana arsitektur biofilik dapat menjawab persoalan dari kejenuhan keseharian manusia itu sendiri?

- Bagaimana merencanakan dan mendesain tempat publik yang dapat bekerja sama

\section{Tujuan} dengan manusia untuk menghilangkan stress tersebut?

Tujuan dari proyek ini adalah merancang suatu tempat publik yang menjadi akses tersendiri bagi pengguna disekitar tapak untuk "cooling down" / "pendinginan" dari stresor yang ada yang menjadi suatu sarana informasi dan edukasi tentang penggunaan desain biofilik secara visual dan non - visual, terutama white noise dan musik dan menjadikannya suatu wadah atau tempat untuk bersosialisasi dan menikmati kebersamaan untuk saling mendukung dan memotivasi satu sama lain.

\section{KAJIAN LITERATUR}

\section{Beyond Ecology menurut ahli}

Menurut Eugene P. Odum (1953), Ekologi adalah suatu pemahaman holistik tentang lingkungan sebagai suatu sistem abiotik dan biotik yang saling berhubungan yang membentuk suatu komunitas tersendiri. Ekologi mempunyai hubungan timbal balik yang saling mempengaruhi satu sama lain, sebagai contohnya adalah, manusia yang hidup dan bertanggung jawab atas unsur yang digunakannya untuk hidup.

Menurut Heidi Liere, Doug Jackson, dan John Vandermeer, heterogenitas spasial adalah hal yang sangat penting dan presisten yang menciptakan suatu interaksi biologis, heterogenitas dibutuhkan untuk bertahannya suatu ekosistem agar menjadi stabil dan berkelangsungan yang melibatkan elemen - elemen yang tidak stabil itu sendiri

Menurut Bratton (2015), desain proses yang berdasarkan jaringan pintar, platform cloud, dan the Internet of Things, mampu menciptakan suatu struktur yang sangat besar melalui pemetaan yang dijelaskan dengan beberapa lapisan

- Earth - Bahan, material, letak geografis

- Cloud-pemetaan global

- City - Jaringan Pintar

- Address - identifikasi, lokasi

- Interface - pengguna dan komputerisasi (AI/VR/AR)Pengguna - manusia / bukan manusia 


\section{Stres dan Stresor}

Sekitar 1,33 juta penduduk DKI Jakarta diperkirakan mengalami gangguan kesehatan mental atau stres. Angka tersebut mencapai $14 \%$ dari total penduduk dengan tingkat stres akut (stres berat) mencapai 1-3\%. Data Dinas Kependudukan dan Catatan Sipil DKI Jakarta menunjukkan jumlah penduduk DKI Jakarta saat ini mencapai 9,5 juta jiwa. Jumlah penduduk yang stres mencapai 1,33 juta (14 persen dari 9,5 juta), sementara stres berat mencapai 95.000-285.000 orang (1-3 persen dari 9,5 juta) (PDKI, 2012). Jadi dapat disimpulkan bahwa, sangat banyak warga Jakarta yang mengalami stres akibat kesehariannya, dan stresor yang terjadi bisa bermacam - macam, berikut adalah beberapa contoh jenis dan faktor - faktor stresor yang ada :

- Faktor durasi

Seberapa lama stresor ini terjadi, hal ini dapat mempengaruhi tingkat hormon stres / hormon kortisol yang dilepaskan oleh manusia, misalnya, orang yang stres terlalu lama akibat kejadian tidak menyenangkan yang terus berulang, dsb.

- Faktor aktifitas keseharian Bisa berupa kemacetan, signal hilang, ataupun hal kecil lainnya yang dianggap remeh namun sangat berpengaruh besar bagi sebagian orang.

- Faktor tekanan Faktor tekanan dapat terjadi akibat hubungan atau interaksi dari 2 belah pihak manusia yang mempunyai efek psikologis sangat besar.

- Faktor perubahan besar yang terjadi di kehidupan Faktor ini bisa berupa hal besar yang langsung berimbas pada keseharian manusia itu sendiri, sebagai contoh, punya anak, menikah, mendapatkan suatu tanggung jawab yang besar, bencana alam, dan masih banyak lagi.

- Faktor Kendali

Manusia sendiri bersifat harus memegang kontrol atau kendali agar dirinya merasa aman dan nyaman, sebagai contohnya adalah pertanyaan ini, apakah kita mempunyai kendali akan stresor ini ?, jika kita tidak mempunyai kendali, maka akan timbul kecenderungan untuk stres dan merasa bahwa kita membutuhkan orang lain atau sesuatu untuk diandlakan.

- Faktor Konflik

Konflik memiliki 2 buah sisi yang harus dipenuhi kebutuhannya tetapi sangat bertentangan dengan suatu norma atau aturan yang berlaku.

- Faktor Frustasi

Sangat berhubungan erat dengan durasi, ketika durasi melebihi batas dan ketika sudah mencoba suatu hal berkali - kali tetapi tidak berhasil, maka manusia akan memiliki kecenderungan untuk memiliki frustasi dan menyerah.

\section{Healing}

Ada beberapa kondisi yang harus dipenuhi manusia agar dapat melakukan penyembuhan, menurut segitiga Maslow, sesuai dengan urutannya dari bawah, ketika yang berada dibawah sudah terpenuhi maka manusia akan membutuhkan yang diatasnya agar kebutuhan healing terpenuhi dengan baik.

Sebagai contoh, dalam dunia abiotik yang berkembang, terdapat beberapa aspek yang berevolusi menjadi suatu keseharian manusia yang bersifat esensial, yaitu bertransportasi. Manusia membutuhkan hal tersebut untuk pergi dari titik A ke titik B dalam kesehariannya, hal ini menimbulkan masalah baru yang sangat berhubungan dengan dunia urban, dimana semua orang membutuhkan hal tersebut sehingga menciptakan lingkungan yang terlalu padat dan akhirnya menimbulkan stresor yang harus dihadapi. 


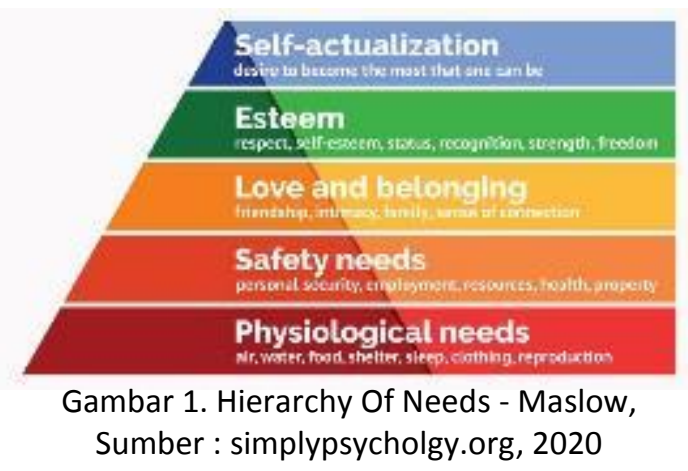

Ada beberapa kondisi yang harus dipenuhi manusia agar dapat melakukan penyembuhan, menurut segitiga Maslow, sesuai dengan urutannya dari bawah, ketika yang berada dibawah sudah terpenuhi maka manusia akan membutuhkan yang diatasnya agar kebutuhan healing terpenuhi dengan baik.

\section{Arsitektur Biofilik Untuk Penyembuhan}

Biophilic Architecture adalah suatu ilmu yang berkembang / berevolusi dari cabang biologi dan psikologi (kembali kepada Beyond Ecology, yaitu alam abiotik yang berevolusi menjadi suatu hal yang baru / mengalami percepatan dan berkembang dengan sendirinya untuk meningkatkan efisiensi dan kerja sama antara manusia, arsitektur, dan alam)

Ada 14 pola dalam desain biofilia yang dapat dimasukan kedalam arsitektur agar menjadi arsitektur biofilik, hal yang perlu dimasukan adalah :

- Koneksi Visual dengan alam

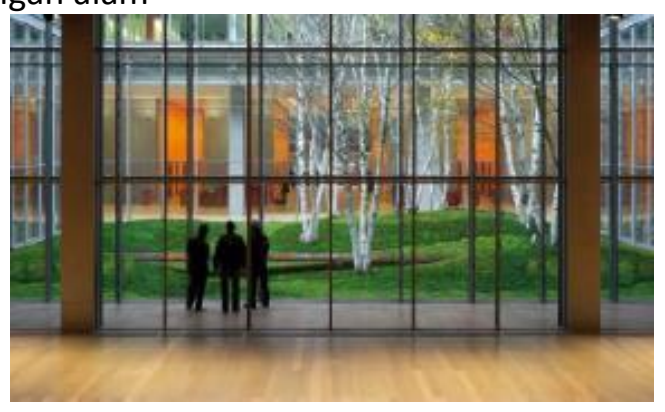

Gambar 2. The New York Times Building Moss and Birch Garden, by Renzo Piano

Sumber : Archdaily, 2011

Sebuah ruang dengan koneksi visual yang baik dengan alam sekitarnya akan terasa lebih menyatu dan menyeluruh. Hal tersebut menjadi suatu pusat perhatian manusia dan bisa menjadi suatu stimulan yang menciptakan situasi yang menenangkan, hal ini juga dapat mengutarakan / mengekspresikan suatu perasaan waktu, cuaca, dan kehdiupan lainnya yang berada dalam lingkungan tersebut.

Pemulihan stress dari koneksi visual dengan alam dapat menurunkan tekanan darah dan detak jantung; mengurangi kelelahan pikiran, kesedihan, dan kemarahan; peningkatan keterlibatan mental/perhatian terhadap sekitar, dan yang terakhir sikap dan kebahagiaan secara keseluruhan.

- Koneksi non - visual dengan alam 


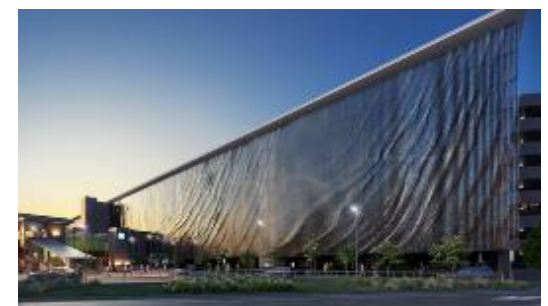

Gambar 3. Brisbane Domestic Terminal Airport

Sumber : Archdaily, 2010

Ruang dengan Koneksi Non-Visual yang baik dengan Alam terasa segar dan seimbang; kondisi ambien dianggap kompleks dan bervariasi tetapi pada saat yang sama akrab dan nyaman, di mana suara, aroma, dan tekstur mengingatkan kita pada alam luar.

White Noise : Penelitian menunjukkan bahwa paparan suara alam, bila dibandingkan dengan kebisingan perkotaan atau kantor, mempercepat pemulihan fisiologis dan psikologis hingga $37 \%$ lebih cepat, mengurangi kelelahan kognitif dan membantu motivasi (Jahncke et al., 2011).

Saraf Olfactory : Sistem penciuman kita memproses aroma langsung ke otak, yang dapat memicu ingatan yang sangat kuat. Praktik dan obat tradisional telah lama menggunakan minyak nabati untuk menenangkan atau memberi energi pada manusia yang sedang sakit atau stres. Penelitian juga menunjukkan bahwa paparan penciuman terhadap tumbuh-tumbuhan dan phytoncides (minyak esensial dari pohon) memiliki efek positif pada proses penyembuhan dan fungsi kekebalan tubuh manusia.

- Kondisi termal / suhu dan aliran udara pada suatu ruang

Penelitian menunjukkan bahwa manusia menyukai tingkat variabilitas sensorik yang stabil dan moderat di lingkungan, termasuk variasi dalam cahaya, suara dan suhu, dan bahwa lingkungan tanpa stimulasi sensori dan variabilitas dapat menyebabkan kebosanan dan kepasifan (misalnya, Heerwagen, 2006) [P4b Catatan Akhir ]. Studi awal di Alliesthesia menunjukkan bahwa sensasi termal yang menyenangkan lebih baik dirasakan ketika keadaan tubuh awal seseorang hangat atau dingin, tidak netral (misalnya, Mower, 1976).

- Kehadiran elemen air

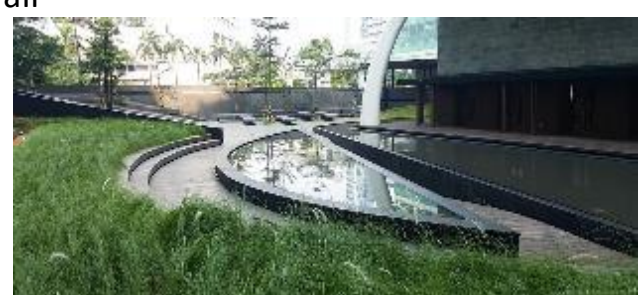

Gambar 4. Pelataran Ramayana, Andra Martin Sumber : tropicagreeneries

Ruang dengan kondisi kehadiran air yang baik akan terasa menarik dan indah. Fluiditas, suara, pencahayaan, kedekatan, dan aksesibilitas masing-masing berkontribusi pada apakah suatu ruang merangsang, menenangkan, atau keduanya. Pola kehadiran air telah berkembang dari penelitian tentang preferensi visual dan respons emosional positif terhadap lingkungan yang mengandung unsur air yang pada dasarnya mengurangi stres, meningkatkan perasaan tenang, dan menurunkan detak jantung dan tekanan darah dari paparan fitur air tersebut; peningkatan konsentrasi dan pemulihan memori yang disebabkan oleh rangsangan visual yang kompleks secara alami; peningkatan persepsi terhadap sekitar dan respon psikologis dan fisiologis ketika banyak indera dirangsang secara bersamaan. Hal ini yang membuat kehadiran air menjadi suatu aspek penting dalam merancang. 
- Kehadiran cahaya yang dinamis dan menyebar

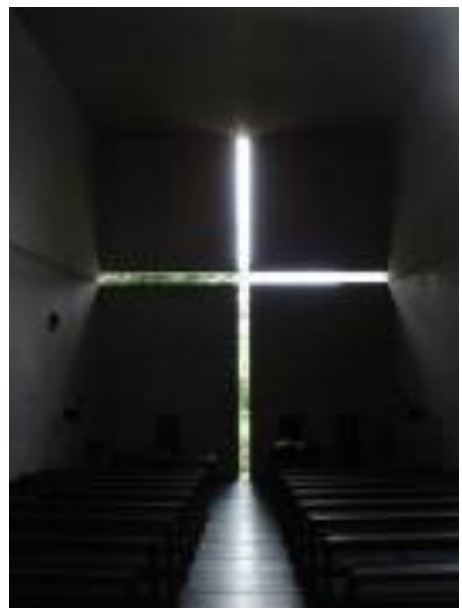

Gambar 5. Church Of Light, Tadao Ando

Sumber : Archdaily

Desain pencahayaan sudah lama digunakan untuk mengatur / mengontrol suasana ruang, dan kondisi pencahayaan yang berbeda yang menimbulkan respons psikologis yang berbeda. Dampak cahaya alami pada kinerja, suasana hati, dan kenyamanan telah dipelajari selama bertahun-tahun di berbagai lingkungan sebagai bidang sains dan desain yang kompleks.

Penelitian awal menunjukkan bahwa produktivitas akan menjadi lebih tinggi di tempat kerja dengan pencahayaan yang baik, penjualan dan laba yang lebih tinggi di toko yang memiliki penchayaan alami, anak-anak belajar lebih baik di ruang kelas dengan pencahayaan alami dan pemandangan. Fokus penelitiannya adalah pada strategi pencahayaan pada keefektifan saat bekerja dan kurang pada biologi manusia. Misalnya, pencahayaan alami yang berkualitas telah dilaporkan merangsang suasana hati yang lebih positif dan secara signifikan mengurangi kerusakan gigi (asupan vitamin D pada sinar matahari pagi) di antara siswa yang bersekolah dengan pencahayaan alami yang berkualitas dibandingkan siswa yang menghadiri sekolah dengan kondisi cahaya rata-rata (Nicklas \& Bailey, 1996).

\section{METODE}

Metode yang digunakan adalah metode lapisan / layering berdasarkan dari data city grid dan juga kebutuhan ruang untuk bersosialisasi, rotasi dan sirkulasi pengguna bangunan, akses, rotasi, pelapisan, pergesaran, dan juga leveling yang memberikan ruang untuk eksplorasi dalam hal tersebut untuk menghasilkan nilai program, fungsionalitas dan estetika. Metode Pendiagraman Layering mengambil data dan potensi dari analisis tapak, analisis pengguna, analisis aktifitas, serta analisis kebutuhan. Lapisan - lapisan ini dibuat untuk lebih memperhatikan dan memberikan efek pemahaman lebih lanjut tentang bagaimana suatu ruang dapat dimanfaatkan untuk menjadi suatu sarana third place yang baik dan mampu menyalurkan stres / mengurangi efek stres yang ada pada keseharian manusia yang berada pada daerah urban padat.

\section{DISKUSI DAN HASIL}

\section{Isu : Kebutuhan Ruang Untuk Pendinginan Stres Keseharian Kehidupan}

Seperti yang kita ketahui, Jakarta adalah salah satu kawasan urban padat yang memiliki tingkat stres sangat tinggi terutama pada bagian Jakarta Pusat dan Jakarta Selatan yang notabenenya adalah pusat bisnis ibu kota. Hal ini menyebabkan urgensi tersendiri yang membutuhkan suatu tempat pelarian sementara dari kepanatan dan kejenuhan tersebut. 


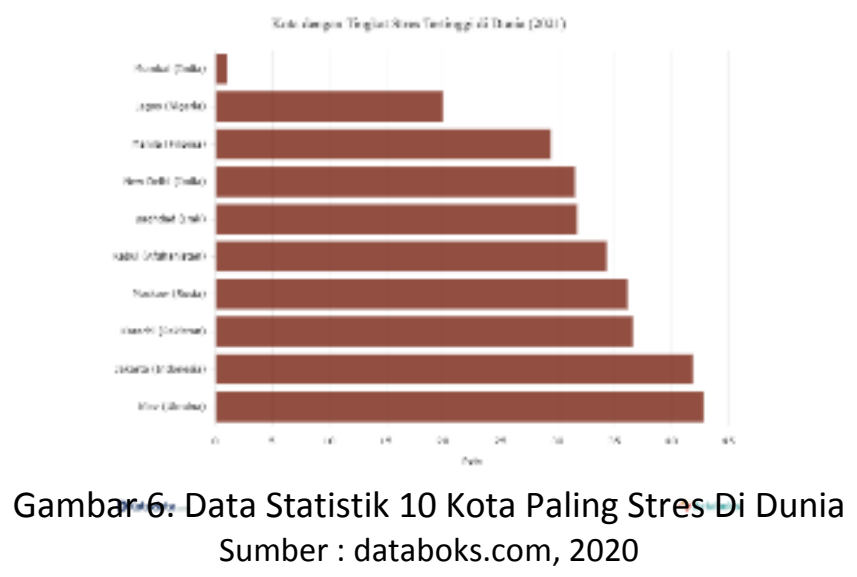

Faktanya adalah daerah pusat kota jakarta yang menjadi pusat perekonomian menjadi salah satu daerah dengan kriteria 10 kota paling stres di dunia berdasarkan laporan The Least and Most Stressful Cities Index 2021, terlebih lagi di masa pandemi seperti ini yang dimana tingkat kemiskinan Jakarta meningkat sebesar $4,69 \%$ yang sangat mempengaruhi sistem ekonomi, tingkat kriminalitas, dan juga masih banyak lagi yang terpengaruh akan hal ini.

\section{Analisis Program : Sejenak dan Informasi White Noise}

Skip Stop, karena pergerakan dari beyond ecology yang mengalami percepatan, maka hal ini dapat dilawan dengan skip stop. Berhenti sejenak dari kegiatan utama untuk melakukan kegiatan yang menenangkan atau melepas penat untuk sementara.

Dalam pengurangan stres, terdapat beberapa hal non - visual yang dapat dimanfaatkan untuk hal tersebut, kembali lagi kepada desain biofilik yang dapat diaplikasikan secara non - visual, white noise sendiri terbagi menjadi beberapa bagian binaural beats yang punya frekuensinya masing - masing.

Manfaat binaural sounds sendiri adalah mengurangi stress, meningkatkan fokus, konsentrasi, dan motivasi, meningkatkan percaya diri, meningkatkan kualitas memori jangka panjang, meditasi lebih dalam, dan meningkatkan psikomotorik, pembagian binaural sounds sendiri adalah sebagai berikut :

\section{- Delta Pattern}

Delta pattern dapat didengar dan dimanfaatkan untuk memiliki dreamless sleep atau tidur yang tidak bermimpi, hal ini adalah salah satu tahap tidur yang sangat nyenyak sehingga dapat membantu proses penyembuhan seperti penyembuhan gangguan saraf / tics pada gelombang otak, alzheimer, dan masih banyak gangguan pada otak lainnya.

- Theta Pattern

Theta Pattern dapat digunakan untuk memperdalam meditasi dengan cepat, meningkatkan kreativitas, dan membantu tidur untuk memiliki R.E.M. Sleep, atau Rapid Eye Movement Sleep. R.E.M. Sleep adalah tahapan tidur dimana ketika kita mengalaminya, kita bermimpi dan menandakan kita tertidur pulas dan dapat meningkatkan kreativitas kita.

- Alpha Pattern

Alpha pattern dipakai hanya sebatas relaksasi saja ketika bertransisi menuju theta lalu delta pattern.

Dari pemakaian dan informasi white noise ini, dapat disimpulkan bahwa, orang - orang yang menggunakan bangunan dapat memanfaatkan dan belajar tentang white noise tersebut untuk 
membantu mereka mengurangi dan melakukan pendinginan sejenak. Selain itu para pengguna juga dapat belajar memanfaatkan white noise sebagai aliran musik baru untuk memabantu healing / penyembuhan / pendinginan dari stres itu sendiri, sehingga muncul program tentang studio yang dapat mewadahi hal tersebut.

Studio ini sendiri memiliki beberapa aspek dan konsep yang dapat digunakan untuk meredam dan membantu orang yang ingin belajar untuk mendapatkan ilmu pengetahuan dan keahlian yang baru, jadi, bukan hanya penghilang stres semata.

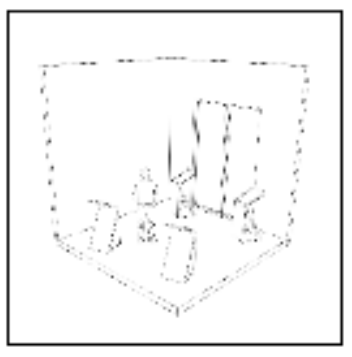

(1)

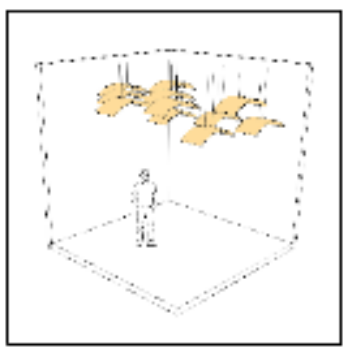

(2)

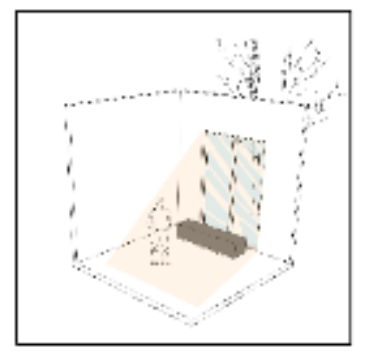

(3)

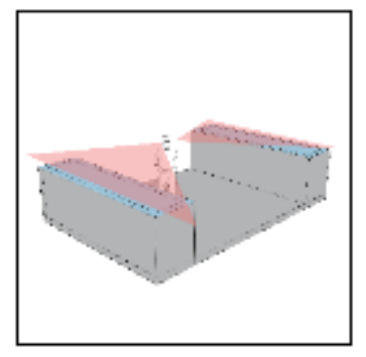

(4)

Gambar 7. Diagram Program Informasi White Noise, Studio, dan Koneksi Visual terhadap Alam, dan Elemen Air

Sumber : Penulis 2021
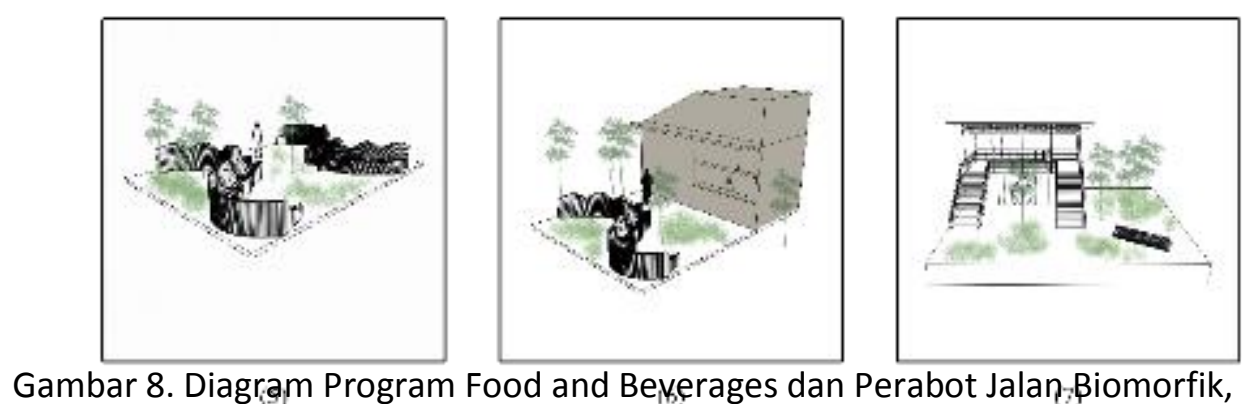

Sumber : Penulis 2021

Selain dari Program Informasi white noise dan studio, terdapat proses sejenak yang dapat diaplikasikan kedalam bangunan, yaitu bentuk - bentuk perabot publik yang biomorfik. Bentuk biomorfik ini sendiri (ilustrasi nomor 5 dan 6) dapat membantu fluiditas pada tapak dan lingkungan yang akan digunakan sehingga membentuk suatu jarak pandang yang lebih mengatur persepsi terhadap lingkungan sekitar agar lebih nyaman untuk dipandang.

Dari segi elemen air, dapat digunakan dengan sesuai jarak pandang manusia yang memiliki tinggi rata - rata $170 \mathrm{~cm}$, pembuatan kolam setinggi $120 \mathrm{~cm}$ dapat membantu manusia yang sekadar lewat untuk merasa tenggelam dan merasakan ketenangan yang dibawakan oleh air tersebut (sebelum berkomuter).

\section{Analisis Kebutuhan}

Dari beberapa program diatas dapat dirumuskan menjadi tabel program ruang yang mempunyai pengembangan kebutuhan, fungsionalitas, dan hubungan yang menyatu dengan tapak itu sendiri, berikut adalah tabel program : 
Tabel 1. Program Ruang

\begin{tabular}{|c|c|c|c|c|c|c|}
\hline PROGRAM & AREA & & KEGIATAN & PENGGUNA & UNIT & LUAS TOTAL (m2) \\
\hline \multirow[t]{3}{*}{1 WHITE NOISE } & AREA PENERIMAAN & R. LOBBY & PENERIMAAN PENGGUNA & UMUM & 1 & 48 \\
\hline & & STUdIO & BELAIAR MENGETAHUI WHITE NOISEE & UMUM & 6 & 96 \\
\hline & & R. INFORMASI WHITE NOISE & BELAAR MENGETAHUI WHITE NOISE & UMUM & 1 & 380 \\
\hline \multirow[t]{5}{*}{2 FOOD AND BEVERAGES } & AREA MAKAN & R. MAKAN INDOOR & MAKAN BERSAMA & UMUM & 1 & 36 \\
\hline & AREA PANGGUNG & R. GANTI & BERGANTI BAUU DAN MENUNGGU & UMUM & 1 & 15 \\
\hline & & R. MIXER & MENGATUR SUARA & UMUM & 1 & 6 \\
\hline & AREA KEDAI & R. KEDAI & MEMBUAT MAKANAN RINGAN & UMUM & 4 & 80 \\
\hline & & GUDANG & MENYIMPAN PERALATAN & UMUM & 1 & \\
\hline \multirow{4}{*}{3 SEJENAK } & AREA TUNGGU & R. DUDUK & MENUNGGU SEBELUM BERKOMUTER & UMUM & 5 & 144 \\
\hline & & JALUR PEJALAN KAKI & AKSES & UMUM & 2 & 534 \\
\hline & TAMAN & TAMAN LANTAI DASAR & MENUNGGU SEBELUM BERKOMUTER & UMUM & 6 & 640 \\
\hline & & TAMAN ROOFTOP FnB & MENUNGGU SEBELUM BERKOMUTER & UMUM & 1 & 345 \\
\hline \multirow[t]{8}{*}{4 SERVIS } & & TOILET & BUANG AIR & UMUM & 2 & 128 \\
\hline & & KAMAR MANDI & MEMBERSIHKAN DIRI SEHABIS / SEBELUM AKTIFITAS & UMUM & 2 & 128 \\
\hline & & R. LOKER & MENYIMPAN BARANG PRIBADI SEBELLUM BELAAAR DI STUDIO & UMUM & 2 & \\
\hline & & R. PANEL DAN GENSET & MENYIMPAN MESIN & PENGURUS & 1 & 16 \\
\hline & & R.POMPA & MENDORONG KE SETIAP UNIT & PENGURUS & 1 & 16 \\
\hline & & STP & MENGOLAH AIR KOTOR & PENGURUS & 1 & 64 \\
\hline & & WTP & MENGOLAH AIR BEKAS & PENGURUS & 1 & 64 \\
\hline & & GWT & MENGOLAH AIR BERSIH & PENGURUS & 1 & 64 \\
\hline \multirow{4}{*}{5 PARKIR } & & MOBIL & PARKIR & UMUM & 1 & 380 \\
\hline & & MOTOR & PARKIR & UMUM & 1 & 125 \\
\hline & & SEPEDA & PARKIR & UMUM & 1 & 36 \\
\hline & & & TOTAL & & & 3384 \\
\hline
\end{tabular}

\section{Analisis Tapak}

Kriteria tapak yang dibutuhkan untuk mewujudkan dan menjalankan program tersebut terdiri dari :

- Mempunyai aksesibilitas tinggi, dan terletak pada pusat perkantoran dan bisnis dengan tingkat stres yang tinggi yang mempunyai fokus menjadi suatu "ekstensi" dari lingkungan tapak tersebut.

- Titik awal dan titik akhir yang bersambungan dan mempunyai kontinuitas yang akan menciptakan kebiasaan dan membuat tapak itu sendiri hidup, contohnya adalah rumah - halte - kantor.

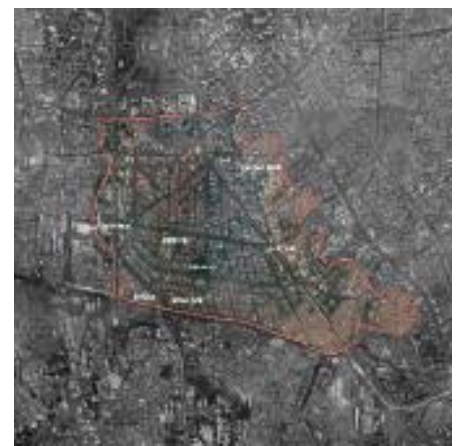

Gambar 9. Lokasi Tapak di Kawasan Menteng

Sumber : Google Maps, Penulis, 2021

Kawasan Menteng menjadi salah satu kawasan daerah urban padat yang memiliki tingkat komplekstias kantor, residental, dan mobilitas yang sangat tinggi, terlebih pada Jalan Jendral Sudirman. Jalan Jendral Sudirman sendiri adalah salah satu arteri utama kota jakarta yang mempunyai tingkat aliran kendaraan dari arah Sudirman - Thamrin sebesar 8,272,5 PCU (Passanger Car Equivalent)/jam, dan untuk arah Thamrin - Sudirman sebesar 8.067,9 PCU (Passanger Car Equivalent)/jam. 


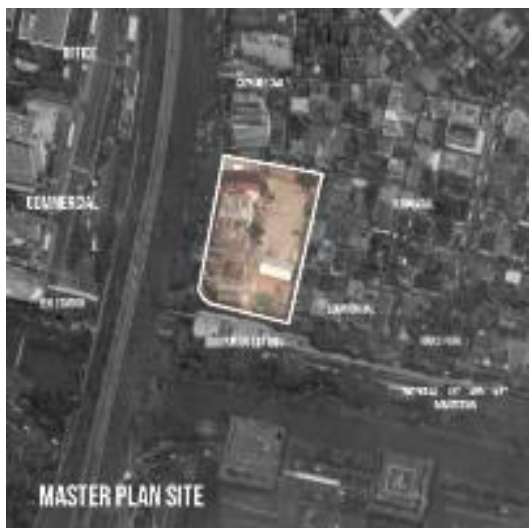

Gambar 10. Lokasi Tapak di Kawasan Menteng

Sumber : Google Maps, Penulis, 2021

Karena bangunan ini harus ditempatkan pada akses yang mudah dijangkau untuk memudahkan orang - orang dilingkungan stress tinggi menggapainya tanpa menambah beban stres, maka, tapak sendiri berada pada dekat stasiun sudirman yang mempunyai potensi akses dan transit yang padat, sehingga dapat bermanfaat untuk proses cooling down itu sendiri.
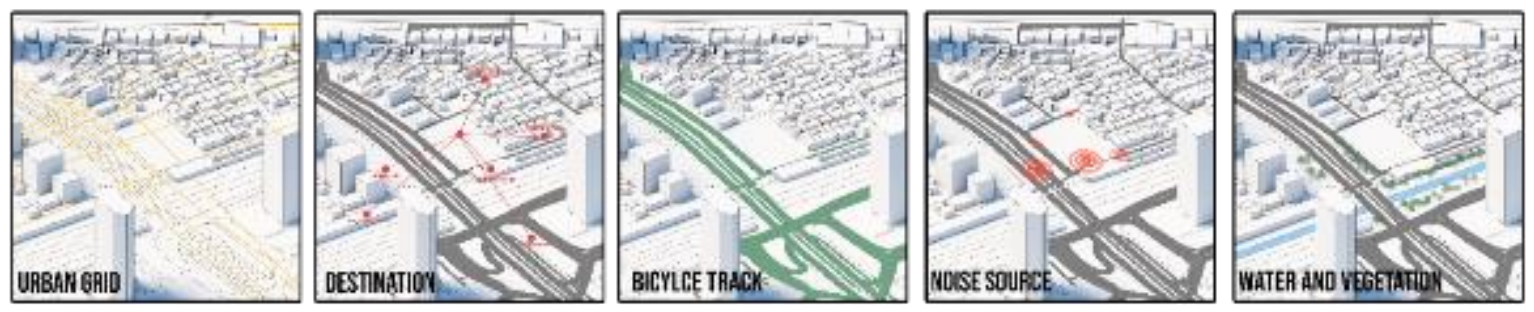

Gambar 11. Diagram Layering Daerah Tapak Blora

Sumber : Penulis, 2021

Pada ilustrasi Noise Source, terdapat beberapa gangguan atau polusi suara yang berada di sekitar tapak, yaitu, kebisingan suara kereta 68-80 dB, kebisingan dari keramaian orang $70 \mathrm{~dB}$, dan kebisingan kendaraan bermotor $80 \mathrm{~dB}$. Hal ini dapat ditangani dengan pemilihan material dan pembuatan noise barrier untuk menghalau dan memecah suara tersebut.

Pada ilustrasi Urban Grid, kita dapat memastikan arah bangunan sekitar dan memanfaatkannya agar tidak menjadi suatu "penghalang" bagi bangunan sekitar, kembali dengan arsitektur biofilik, jarak pandang penghijauan dari dalam dan luar tapak sangat berpengaruh untuk melakukan pendinginan dan pelepasan stres tersebut.

Lapisan / Layer Destination juga dapat di tambahkan untuk mengatur dan menjaga agar gubahan massa bangunan menjadi suatu area transit dan transisi dari bangunan sekitar agar dapat memecah keramaian sebelum menuju ke destinasi tersebut. 


\section{Analisis Aktifitas}
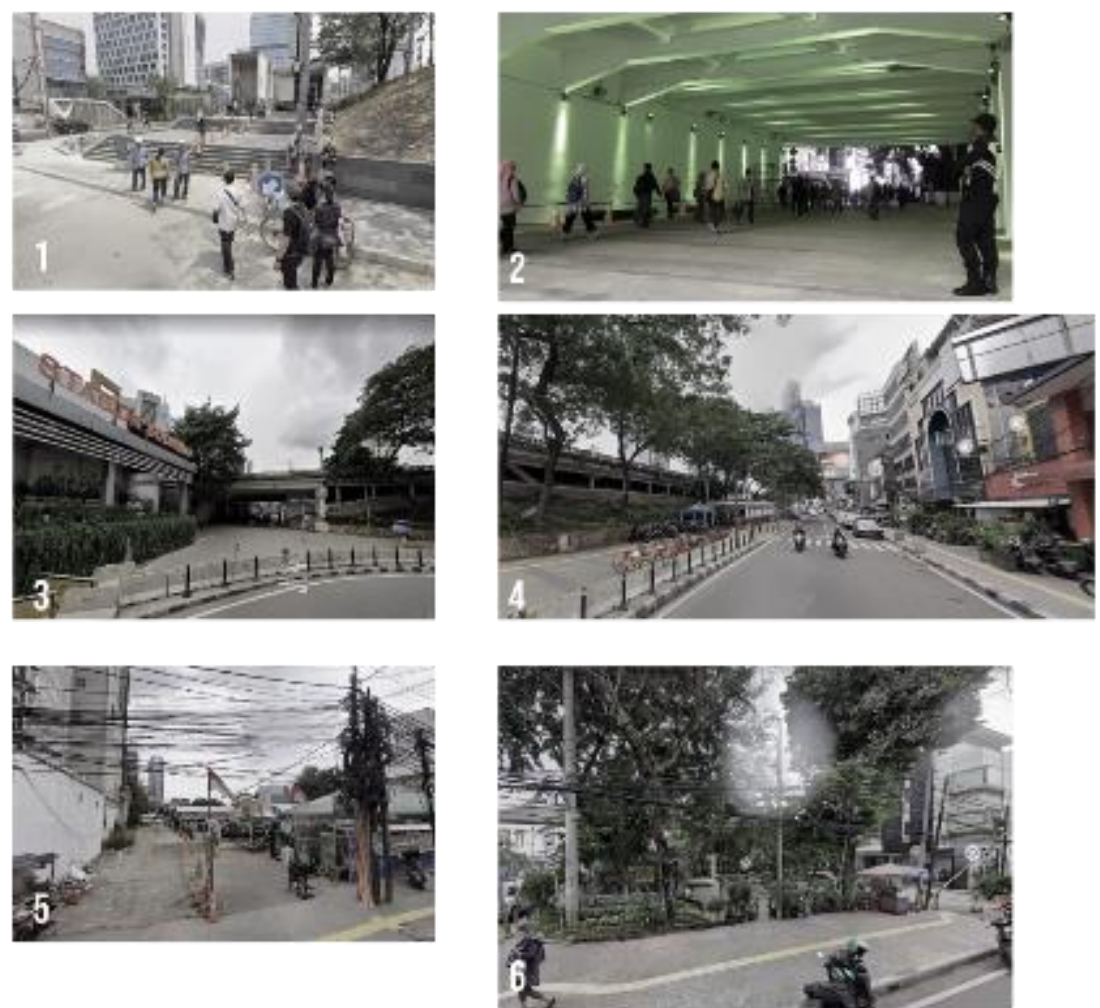

Gambar 12. Foto Eksisting Sekitar Tapak Sumber : Google Maps, Penulis, 2021

Urutan kegiatan yang terjadi mulai dari foto nomor 1 hingga 6 adalah, pengguna yang turun dari stasiun dukuh atas, menuju terowongan Blora, menuju ke stasiun sudirman, lalu foto nomor 4 adalah area depan tapak, foto nomor 5 adalah area belakang tapak, dan foto nomor 6 adalah Taman Kudus Sudirman

\section{Proses Gubahan Massa}

Layering pada daerah tapak Blora menjadi suatu acuan dalam membuat gubahan massa yang menerima dan membuka diri untuk sebuah ruang publik terbuka hijau sesuai dengan arsitektur biofilik di tengah kota. Pada tahap 1 dapat terlihat penyesuaian City Grid yang membuat bangunan sendiri menjadi suatu "ekstensi" dan pemecahan suara bagi stasiun Sudirman.
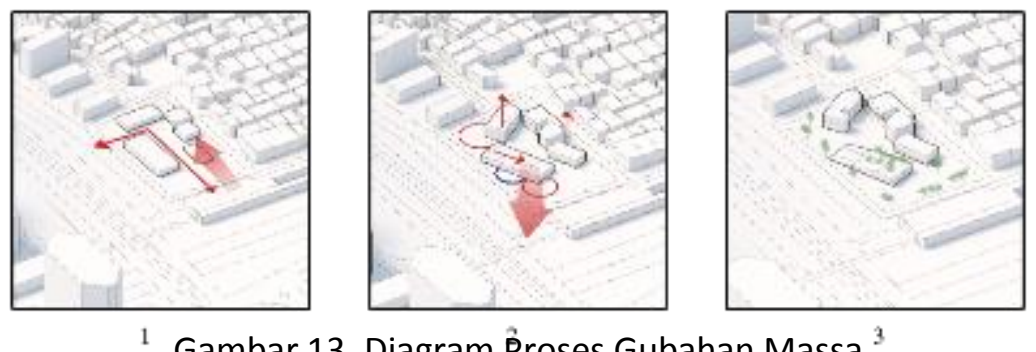

${ }^{1}$ Gambar 13. Diagram P̉roses Gubahan Massa ${ }^{3}$

Sumber : Penulis, 2021

Pada tahap 2, posisi bangunan dibagi menjadi menjadi beberapa bagian yang terdiri dari, bagian informasi white noise, bagian servis, bagian ruang tunggu / duduk, dan bagian food and beverages. Bagian food and beverages sdan area duduk dimiringkan sebanyak $30^{\circ}$ untuk 
memecah suara kebisingan yang masuk dan juga untuk memberikan kesan tertutup pada bagian dalam tapak.

Pada tahap 3, bangunan sudah di potong sedemikian rupa dibagian penerimaan awal untuk membeirkan jarak pandang lebih dan fluiditas jarak pandang untuk penghijauan, serta, pada bagian atas food and beverages, terdapat open space yang digunakan untuk menyaring polusi, tempat penghijauan, dan juga tempat publik terbuka untuk menunggu dan menikmati alam buatan yang berkesinambungan dengan arsitektur biofilik itu sendiri.

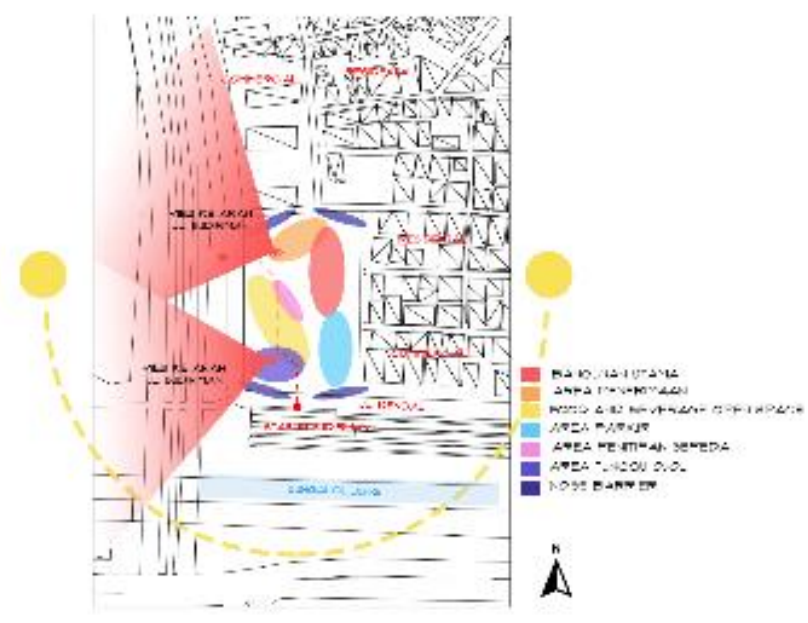

Gambar 14. Diagram Zoning Massa Berdasarkan Layer Kebutuhan Ruang Sumber : Penulis, 2021

\section{Hasil Perancangan}

Setelah pembentukan gubahan massa yang berkembang dari kebutuhan ruang dan layering, askes utama tapak dibuat agar terkesan membuka dan menerima dengan mampunyai plaza yang luas (1) dan ketika masuk bangunan itu sendiri, disambut dengan split level yang menambah kesan tersebut (3). Selain itu, bangunan sendiri memiliki bukaan - bukaan jendela yang besar untuk memaksimalkan pencahayaan alami dari konsep arsitektur biofilik yang digunakan, tujuannya adalah untuk merangsang dan menajaga kinerja otak agar terpapar cahaya matahari alami yang menimbulkan perasaan positif untuk beristirahat sejenak dari kepenatan keseharian pengguna bangunan. Setelah itu, dilanjutkan dengan area tunggu yang berada pada area depan tapak (2), orang dapat membeli makanan atau minuman secara langsung atau menikmati "air" yang memeluk bangunan food and beverages itu sendiri.

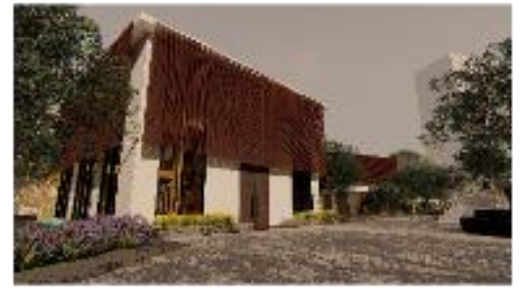

(1)

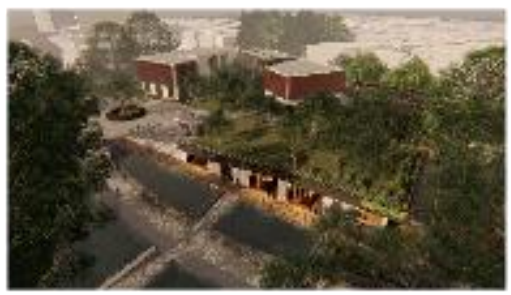

$\{2\}$

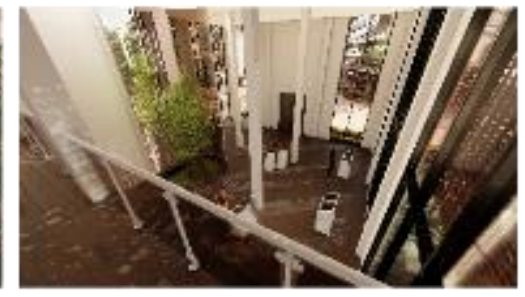

(3)

Gambar 15. Area Penerimaan - Bird Eye View - Pusat Informasi White Noise Sumber : Penulis, 2021

Penambahan kisi - kisi pada bagian depan tapak (1) juga menjadi suatu konsep yang diperuntukan utnuk penciptakan pandangan visual dari bayangan yang terbentuk dari cahaya alami matahari dan untuk menjaga suhu dalam bangunan agar tetap stabil dan sejuk. Kisi - kisi tersebut terbuat dari kayu bingkarai yang kuat terhadap cuaca dan iklim Jakarta yang sering berubah dengan cepat. 


\section{KESIMPULAN DAN SARAN KESIMPULAN}

Stres yang dialami manusia dapat ditangani jika kita mengetahui sumber stresor dan cara penanganan yang tepat, konsep dari beyond ecology yang ada dalam proyek ini diharapkan dapat terus berkembang untuk melawan keterlemparan manusia (M. Heidegger) dari kesehariannya yang membuatnya monoton dan tidak berarti. Hubungan alam dan manusia dapat lebih dimaksimalkan tanpa perlu adanya korban yang signifikan dari kedua belah pihak. Peran manusia disini sangat penting untuk memberikan dampak atau efek yang akan menjaga kesinambungan alam agar lebih bermanfaat bagi kedua belah pihak, kawasan urban padat akan terus bertambah seiring berjalannya waktu dikarenakan laju pertumbuhan penduduk / mortality rate yang terus meningkat setiap tahunnya, lebih tepatnya $0,9 \%$ per - tahun (sumber : data.unicef.org). Ketika hal ini terjadi maka akan ada percepatan beyond ecology lagi dan banyak pribadi - pribadi yang harus memenuhi kebutuhan masing - masing dan mempunyai ego yang harus dipuaskan tanpa mementingkan alam itu sendiri. Dari arsitektur biofilik sendiri, kita dapat belajar bahwa kita tidak harus bekerja melawan alam, tetapi belajar untuk bekerja sama dan mempelajari alam yang akan bermanfaat bagi kehidupan manusia dan mengeluarkan manusia dari stres berlebih atau mengurangi stresor yang ada dalam tahap proses healing tersebut.

\section{SARAN}

Proyek ini dapat diteruskan untuk menjadi suatu tempat singgah dari keterpurukan manusia yang hanyut di dalam kesehariannya dan butuh alam dan arsitektur sebagai jawaban dari permasalahan mereka di daerah urban padat.

\section{REFERENSI}

Balling, J.D., \& Falk, J. H. (1982). Development of Visual Preference for Natural Environments. Environment and Behavior. Washington, DC, U.S.A. : American Psychological Association

Barton, J. \& J. Pretty (2010). What Is the Best Dose of Nature and Green Exercise for Improving Mental Health. Environmental Science \& Technology. Colchester CO4 3SQ, U.K. : University of Essex

Bratton, B. H. (2015). The Stack: On Software and Sovereignty. London, U.K. : Massachusetts Istitute of Technology.

Browning, W.D., Ryan, C.O., Clancy, J.O. (2014). 14 Patterns of Biophilic Design. New York, U.S.A. : Terrapin Bright Green Ilc.

databoks.katadata.co.id. 8/7/2021, 15.30 WIB. "Jakarta Masuk Daftar 10 Kota Paling Stres di Dunia".https://databoks.katadata.co.id/datapublish/2021/07/08/jakarta-masuk-daftar-10 kota-paling-stres-di-dunia-pada-2021\#

data.worldbank.org. 2019. "Mortality Rate, Neonatal (per 1000 live births), Diakses dari https://data.worldbank.org/indicator/SH.DYN.NMRT

Eugene P. Odum (1953). Fundamentals of Ecology. Philadelphia, U.S.A. : W. S. Saunders.

healthline.com. 6/10/2017. "Do Binaural Beats Have Health Benefits?". Diakses dari https://www.healthline.com/health/binaural-beats 
jakpuskota.bps.go.id.20/5/2020. "Kota Administrasi Jakarta Pusat Dalam Angka". Diakses dari https://jakpuskota.bps.go.id/publication/2020/05/20/b983d8ea819b7431514d34db/kotaadmnistrasi-jakarta-pusat-dalam-angka-2020.html

Joye, Y. (2007). Architectural Lessons From Environmental Psychology: The Case of Biophilic Architecture. Review of General Psychology

Nicklas, M.H. \& G.B. Bailey (1996). Student Performance in Daylit Schools. Innovative Design. Raleigh, North Carolina, U.S.A.: Innovative Design

P2PTM Kemenkes RI (2018). Stresor Dalam Kehidupan Manusia. Jakarta, Indonesia : Kemenkes RI 2018

Tsunetsugu, Y. \& Y. Miyazaki (2005). Measurement of Absolute Hemoglobin Concentrations of Prefrontal Region by Near-Infrared Time-Resolved Spectroscopy: Examples of Experiments and Prospects. Journal of Physiological Anthropology and Applied Human Science

Tsunetsugu, Y., Y. Miyazaki, \& H. Sato (2007). Physiological Effects in Humans Induced by the Visual Stimulation of Room Interiors with Different Wood Quantities. Journal of Wood Science 